\title{
METHODOLOGICAL APPROACH FOR THE DELIMITATION OF "NO BATHING AREAS" IN MARINE COASTAL ZONES CLOSE TO THE OUTLETS OF NATURAL AND ARTIFICIAL WATER COURSES IN BASILICATA REGION, ITALY
}

\author{
MICHELE GRECO ${ }^{1,2^{*}}$, NICOLA UNGARO ${ }^{3}$, GAETANO CARICATO $^{3}$, GIOVANNI MARTINO $^{1}$, \\ LORENA DI GIUSEPPE ${ }^{2}$, GIUSEPPE GIMBATTI ${ }^{2}$, PATRIZIA MAURO $^{2}$, ANNA MONTELLA $^{2}$, \\ GIOVANNI MUSSUTO ${ }^{2}$, MARIA E. SALERA ${ }^{2}$, DOMENICO FARAONE ${ }^{3}$, \\ CARMELA DI GRAZIA ${ }^{3} \&$ PASQUALE DE LUISE ${ }^{2}$ \\ ${ }^{1}$ Engineering School of University of Basilicata, Italy \\ ${ }^{2}$ Regional Environmental Research Foundation - FARBAS, Italy \\ ${ }^{3}$ Environmental Protection Agency of Basilicata, Italy
}

\begin{abstract}
The Basilicata coasts, both Tyrrhenian and Ionian, are characterised by a considerable number of water courses both natural and artificial, which represent critical points for influence on marine bathing water quality. In such a context, according to the Water Framework Directive (2000/60/EC) and Water Bathing Directive (2006/7/EC), it has been necessary to carry out a systematic water quality check integrating the ordinary monitoring activity lead by the Regional Environmental Protection Agency of Basilicata (ARPAB) in order to provide a preliminary characterization of the marine waters for bathing purposes. The adopted methodological approach suggests to apply a 1-D model for pollutant transport and diffusion/dispersion in water bodies in order to perform a preliminary assessment of the width of the "no bathing area," including the water-course mouth. Calibration has been provided using episodic data collected in some of the artificial and natural water courses flowing into the Basilicata seas. Moreover, the assessment of the longshore width of these "no bathing areas" is generally aligned with the middle axis of the water course mouths. It has been obtained by simulating the diffusion/dispersion plume using episodic data and systematically collected ones during the bathing seasons, starting from 2011. In such a framework, the model results suggest a differentiation between Ionian and Tyrrhenian coasts due to the local littoral morphology as well as to the natural deltas and artificial outlets. Therefore, in "no bathing areas" of the Ionian coast, the methodological approach proposes a width of $40 \mathrm{~m}$ for artificial water course outlets and $100 \mathrm{~m}$ for natural water course outlets. However, the proposed "no bathing area" of the Tyrrhenian coast is $20 \mathrm{~m}$ wide with only one artificial water course outlet.
\end{abstract}

Keywords: no bathing area, water framework directive, bathing water directive, marine waters monitoring, diffusion model.

\section{INTRODUCTION}

The main goal of the European Water Framework Directive (WFD) issued by the European Commission [1] is to ensure water quality protection and improvement throughout the European Union (EU) by enforcing a common water resource management and control policy as well as by defining powerful strategies aimed to reduce sea water pollution and coastal resource overexploitation. A Directive was promulgated in 2000 (Dir 2000/60/EC), it defines the deadlines to reach the objective of a good ecological level of integrity for all the types of water bodies: rivers, lakes, transitional water, coastal water and groundwater.

* ORCID: http://orcid.org/0000-0002-3986-7117 
In Europe, bathing water quality management is regulated by the Directive 2006/7/EC (WBD) of the European Parliament and of the Council of 15 February 2006 [2], repealing the Directive 76/160/EEC [3]. The Directive 2006/7/EC aims to preserve, to protect and to improve the quality of the environment as well as to protect human health by supplementing the Directive 2000/60/EC. The Directive 2006/7/EC lays down provisions on monitoring and classification of bathing water quality, its management and its public information.

Water is a limited natural resource and-its quality should be protected, defended, managed and treated. In particular surface waters are renewable resources with limited capacity for recovery after a negative impact caused by human activities. In order to increase the efficiency and rational use of natural resources, the Directive 2006/7/EC should be closely coordinated with other Community legislation concerning water, such as the Council Directives 91/271/EEC [4], of 21 May 1991 on urban waste water treatment, and the Directive 91/676/EEC [5] of 12 December 1991 on the protection of water against pollution by nitrates from agricultural sources and the Directive 2000/60/EC of the European Parliament and of the Council, of 23 October 2000 establishing a framework for Community action in the field of water resources.

"Bathing water" is surface, current, or lake fresh water and sea water where bathing is expressly authorised or not prohibited. In Basilicata the monitoring of bathing waters takes place from 1 April to 30 September of each year, with monthly sampling frequency and the reference indicators of microbiological pollution are Intestinal Enterococci (I.E.) and Escherichia coli (E.C.). The concentration in the surface waters of these indicators highly depends on the efficiency of waste water collection and treatment systems as well as on the self-purification ability of the receiving water bodies. This ability is often favoured by natural factors such as the hydrological characteristics [6], [7] and the presence of vegetation [8], [9]. Surveying and quantifying microbial pathogens can be quite expensive and complex, so the assessment of water microbiological quality is based on the quantification of indicators of faecal pollution [10]-[12].

All along the Basilicata coasts (or Lucanian coasts), the only "no-bathing" areas are actually close to the deltas/outlets of water courses; it was stated by a regional decision as a precautionary principle without any scientific base. In such context, according to the WFD and WBD, in 2017 the Regional Environmental Research Foundation (FARBAS) proposed to carry out a systematic water quality survey in order to provide a preliminary characterization of the deltas/outlets sea waters quality status for bathing purposes. If not significant changes in the marine-coastal environment occur and the boundary variables (i.e. solar radiation, salinity, temperature, $\mathrm{pH}$, and nutrient availability) are almost stable, the assessment of the E.C. concentration can be obtained performing only specific microbiological analyses [13], [14]. Among fecal coliforms, E.C. is recognized the best indicator of fecal pollution [15]. Furthermore, numerical forecasting modelisation is a robust tool capable to support monitoring activities outlining the criticalities of the physical coastal system. It also provides useful information related to the inland pressure scenarios and pollutant sources. From a modelling point of view, indeed, the integrated and combined use of one-dimensional models with a complex two or three-dimensional models might be a valuable facility for investigating the pollutant propagation in space and time of E.C. in the coastal marine area [16].

The aim of this study is to propose an expeditive methodological approach physically based on the searching of "no bathing areas" in order to reduce the pollution impact on the littoral and its effect on the human health and tourism. Moreover, this study improves the knowledge of the coastal water quality state. 


\section{THE LUCANIAN TYRRHENIAN AND IONIAN COASTS}

The study concerns the whole Lucanian coast both on Ionian and Tyrrhenian littorals, interesting about $37 \mathrm{~km}$ and $25 \mathrm{~km}$ respectively, paying particular attention to the outlets of the natural and artificial water courses.

The Ionian coast starts from Metaponto (NE) (Fig. 1) to Nova Siri (SW) where the rivers Bradano, Basento, Sinni, Cavone and Agri flow. The Tyrrhenian coast mainly concerns Maratea area.

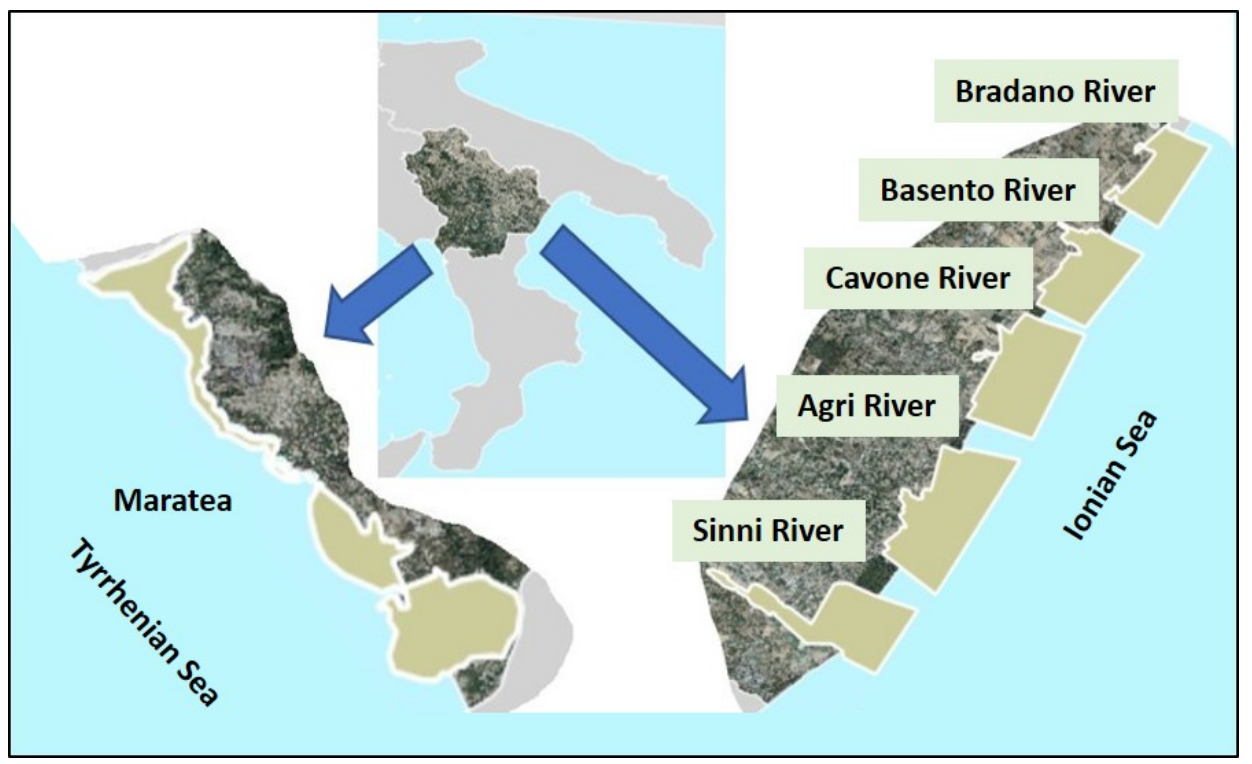

Figure 1: Study areas along the Ionian and Tyrrhenian Lucanian coasts and the Site of Community Importance by Habitats Directive (92/43/EEC).

The Ionian littoral is characterized by the presence of Sites of Community Importance (SCI) sensu "Habitat Directive" (1992/43/CEE):

- SCI "Costa Ionica foce Bradano

- SCI "Costa Ionica foce Basento"

- SCI "Costa Ionica foce Cavone"

SCI "Costa Ionica foce Agri" The Tyrrhenian coast is characterized by the presence of Marine Nature Reserve "Costa di Maratea" rich in marine benthic communities and Posidonia oceanica meadows, as well as the following SCI:

- SCI "Acquafredda di Maratea"

- SCI "Marina di Castrocucco"

- SCI "Isola di S. Ianni e Costa prospiciente"

Moreover, along the Ionian coast there are 9 outlets of the artificial remediation channels which drains water to improve agricultural activities, which represents the main economic source of the area. 


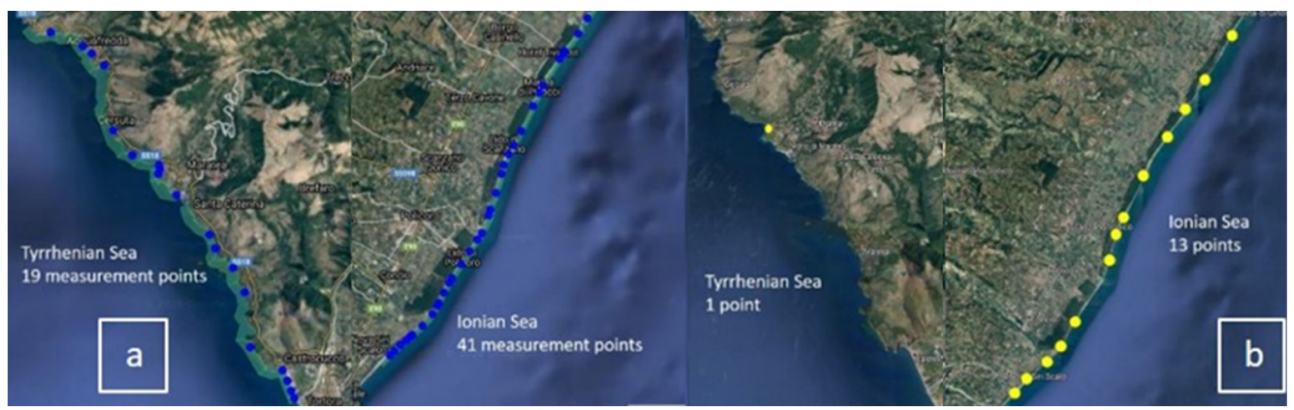

Figure 2: (a) Bathing water, ordinary monitoring network of ARPAB [17]; and (b) Monitoring added points for bathing waters close to natural and artificial water course outlets along the Lucanian coasts.

\section{METHODOLOGICAL APPROACH}

The rationale of the work is the realization of measurement surveys integrating the ordinary monitoring activities systematically carried out by ARPAB during the bathing season since 2011. In particular, in addition to the 60 points (19 on the Tyrrhenian Sea and 41 on the Ionian Sea) routinely monitored by ARPAB (Fig. 2(a)), 14 additional points were considered close to the outlets of natural and artificial water courses [17], 13 on the Ionian coast and 1 on the Tyrrhenian coast (Fig. 2(b)). That is, 74 control areas on $61.52 \mathrm{~km}$ of coastline means in average one sampling point each $830 \mathrm{~m}$ of littoral, leading the Basilicata region one of the most monitored regions in Italy.

The additional monitoring was carried out by the FARBAS technicians in collaboration with the personnel of the ARPAB. Sampling and analyses were carried out monthly during the bathing season (April-September) for three-year period (2017-2019).

In the monitoring surveys, a multi-parameter YSI Pro Plus probe was used for the additional parameter $\mathrm{pH}$, ORP, conductivity, dissolved oxygen and pressure (as proxy of depth). The microbiological analyses [18] of the samples were carried out at the ARPAB Microbiology Laboratory. The methods employed were the UNI EN ISO 7899-2 [19] for Intestinal Enterococci (I.E.) and UNI EN ISO 9308-1 [20] Escherichia coli (E.C.) respectively [21].

Each added monitoring point was fixed aligned to the middle of the outlet, both for natural and artificial water courses, while the width of the investigated area for the study was estimated through the implementation of 1-D model coherent to the microbiological indicators E.C. and I.E. temporal and spatial diffusion dynamics.

Further, the 1-D exponential spatial decaying law was adopted as first order assessment of the width of the no-bathing area to be considered in the study, while a 2-D model Delft3D [22], [23] software was subsequently applied in order to obtain the analysis scenarios for further evaluation of the "no bathing area" related to the local coastal hydrodynamics and health risk according to the Directive 2006/7/EC.

Through the Delft3D-Flow-Wave-D-WaQ coupled modules [24], [25], critical scenarios for hydrodynamic predictive simulations with limit values of E.C. and I.E. for marine waters (E.C. $500 \mathrm{UFC} / 100 \mathrm{ml}$ and I.E. $200 \mathrm{UFC} / 100 \mathrm{ml}$ ) were assumed in order to evaluate the distance from the outlets where there is not microbiological pollution risk. 
Specifically, the Delft3D-D-WaQ (Water Quality) module exploits the hydrodynamic conditions (velocity, water elevation, density, salinity, viscosity and diffusivity) calculated in the module Delft3D-Flow-Wave for given climate sea wave condition (wave height, wavelength and wave period) and simulates water quality by solving the diffusion equation on a fixed computational grid for a wide range of modelling substances.

The simulation scenarios refer to well defined space-time domain and time-spatial conditions of short, medium or long period that can be simulated on more or less detailed spatial domains depending on the required performances and available data [26], [27]. Therefore, the choice of the model and the subsequent methodological approach is a crucial point, since systematic and/or numerical errors can be generated compromising the value of the results as consequence of the approximation induced by the quality of the employed data [28]. The Delft3D-Flow-Wave-D-WaQ coupling module, both in steady and unsteady conditions, is implemented and calibrated on pre-processing, processing and post-processing operations. The pre-processing phase deals with the preliminary analysis and characterization of the topo-bathymetric and climate wave input data, while the processing phase runs the simulation scenarios on a computational grid under defined initial and boundary conditions (I.E. and E.C. initial concentrations at the outlets) (Fig. 3).

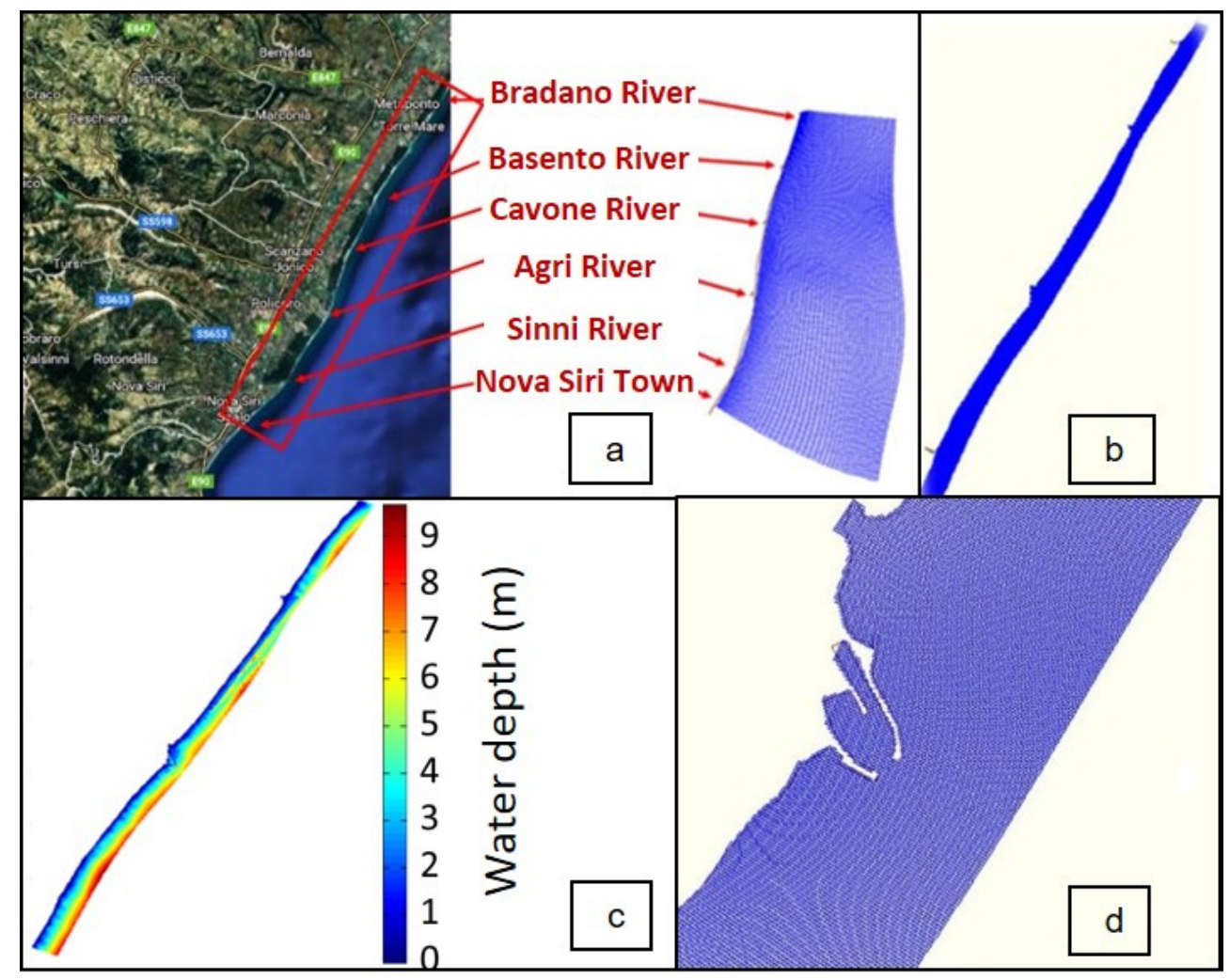

Figure 3: (a) Computational domain; (b) Computational grid; (c) Bathymetric domain; and (d) Detail of computational grid around the port (Argonauti harbour and Basento River delta). 


\section{RESULTS AND DISCUSSION}

The proposed methodological approach was applied for the assessment of the "no bathing area" to be assumed for further study on the marine water quality. The preliminary implementation of 1-D diffusion model refers to episodic data collected on one of the nine artificial channel outlets (Nova Siri) in September 2016. In such a case, the measurements have been collected in the middle of the mouth and at $50 \mathrm{~m}$ and $150 \mathrm{~m}$ far away from the outlet along the coast, both sides, following ordinary procedures with few centimetres of wave height and calm weather conditions. Fig. 4, in the limits of the limited amount of data, reports the calibration curves for both parameters E.C. and I.E. and the relative decaying curves which allow us to assume the width of the study areas across the artificial water course outlet of about $40 \mathrm{mt}$. It is useful outline that the highest observed value for both parameters, 2600 and $634 \mathrm{UFC} / 100 \mathrm{ml}$ for E.C. and I.E. respectively, sensitively exceed the regulation values admitted for bathing into fresh waters but the rate of decay is reasonable high in the middle of outlet (BF curves: E.C. 1000 UFC/100ml and I.E. 500 UFC/100ml threshold values for fresh-internal waters).

Moreover, the 2-D model Delft3D-Flow-Wave-D-WaQ coupling module was applied to the whole of the Ionian coast in order to have further information concerning the response of the system and the robustness of the preliminary assessment. In detail, the simulations were carried out assuming the following inputs and generally conservative boundary conditions: almost quiet sea water condition ( $5 \mathrm{~cm}$ wave height), no wind and longshore currents (typical of the seasonal climate features) which generally reduce the pollutant dispersion effect [29], average summer water discharges for both rivers and artificial channels and the values of I.E. and E.C. in such discharges were fixed to 500 and $1000 \mathrm{UFC} / 100 \mathrm{ml}$ respectively, corresponding to the limits of Law adopted for bathing compliance in the fresh water bodies.
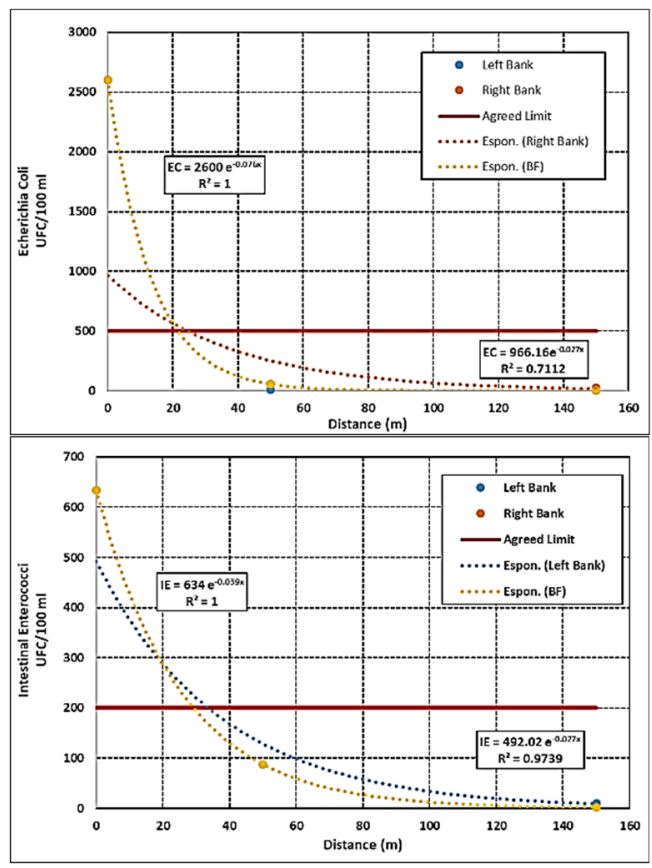

Figure 4: Outputs of the 1-D model coherent to E.C. and I.E. temporal and spatial diffusion dynamics to assess the width of the study areas across the water courses outlets. 

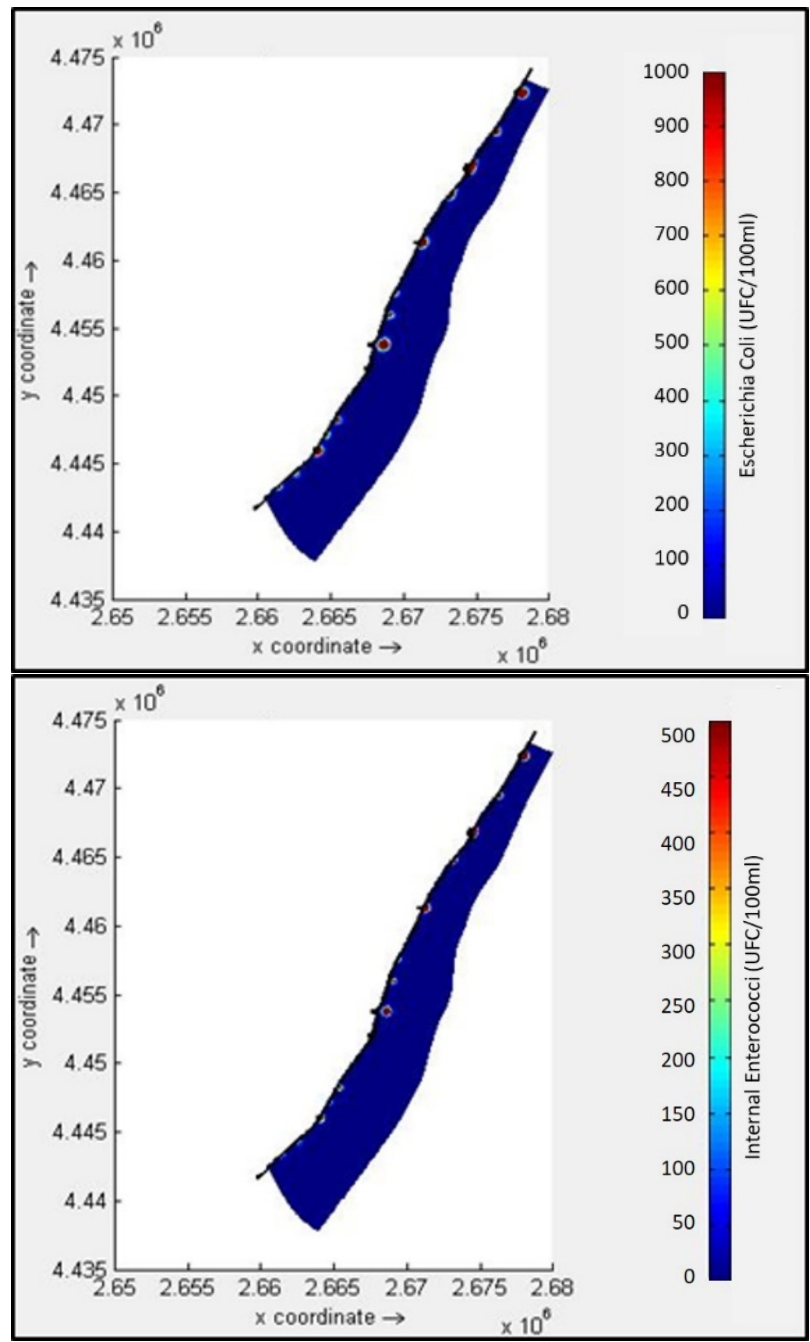

Figure 5: Study scenario according to the input values of $1000 \mathrm{CFU} / 100 \mathrm{ml}$ for E.C. and $500 \mathrm{CFU} / 100 \mathrm{ml}$ for E.I. at the water course outlets.

Fig. 5 reports the results of the 2-D model Delft3D-Flow-Wave-D-WaQ coupling module simulations referred to the whole littoral for both parameters, in which are shown the cumulative effects along the coast. Moreover, the simulation where addressed to define the width of the "no bathing area" to be considered in order to carry out monitoring activities for the outlets influence assessment.

In Figs 6 and 7 are reported, as examples, the numerical results found for natural and artificial outlets, respectively, and the evaluated distance at which the concentration of the microbiological indicators are lower than the regulation limits for marine waters. In details, Fig. 6, which refers to two different deltas (Cavone River and Basento River) outlining the numerical results under the imposed boundary conditions previously discussed. That is, it shows that close to the river deltas the values of concentration fall within the limits of Law 
for the bathing water for both the microbiological indicators (I.E. and E.C.) already at a distance of about $30 \mathrm{~m}$ from the middle of the outlet well according to the expeditive 1-D model forecasting.

On the other hand, for the artificial water courses the outputs are quite different with respect to those observed for natural rivers even due to the low average values of the water discharge assumed flowing into the sea. That is, the discharges assumed in the 2-D model Delft3D-Flow-Wave-D-WaQ coupling module simulations are the average seasonal values observed during the bathing period (April-September), more or less close to 0.1 cumes, which allow us to have a mean rates for both microbiological pollutant sensitively low. Thus, the numerical simulations of artificial water course outlets report a negligible width of the no bathing area.

In such a framework, the model results suggest a differentiation between natural and artificial outlets as well as for the Ionian and Tyrrhenian coasts, the last due to the local littoral morphology and also general climate wave which induce further mixing effect influencing the decay curves of both E.C. and I.E. microbiological pollutant concentrations.

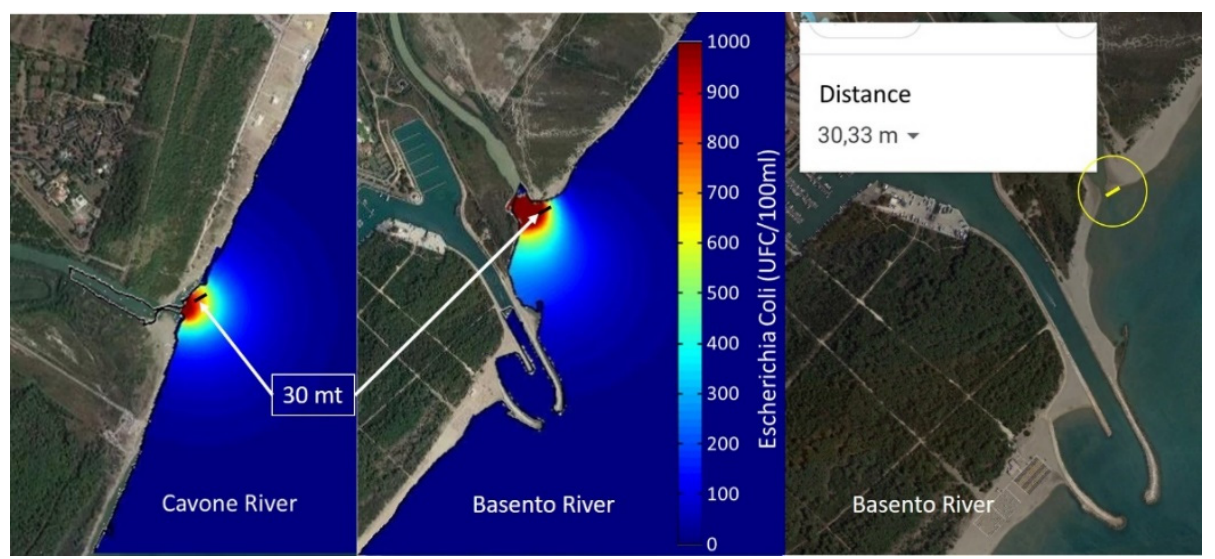

Figure 6: Simulation results for the river deltas under the boundary conditions of 1000 CFU/100 ml for E.C. and $500 \mathrm{CFU} / 100 \mathrm{ml}$ for E.I. at the water course outlets.
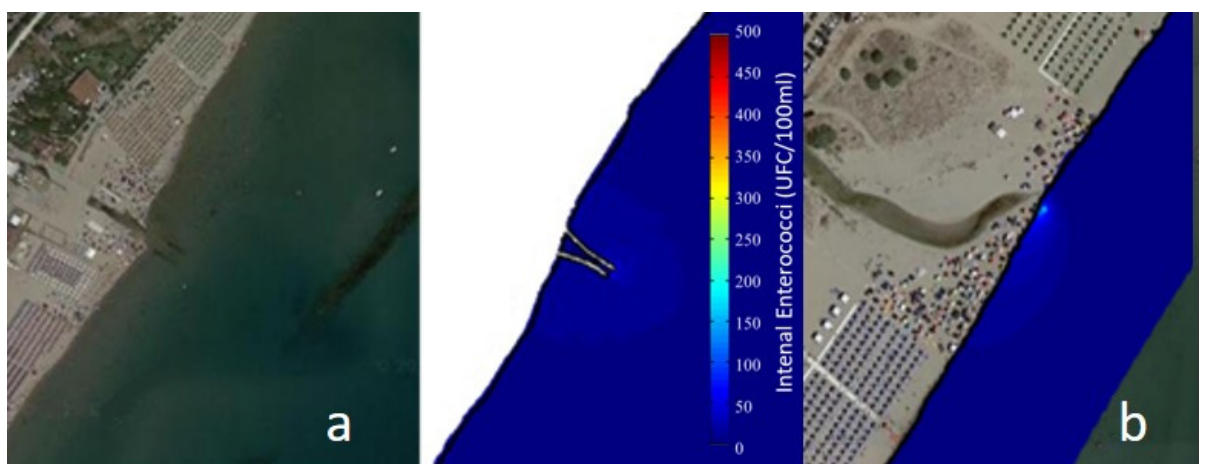

Figure 7: Simulation results for the artificial outlets under the boundary conditions of 1000 CFU/100 ml for E.C. and $500 \mathrm{CFU} / 100 \mathrm{ml}$ for E.I. at the water course outlets. 


\section{CONCLUSIONS}

The routine monitoring plan for Basilicata's bathing waters provides to check 60 bathing areas on about $61.5 \mathrm{~km}$ of littoral.

Starting from the 2017 bathing season, additional control points were added in marinecoastal areas corresponding to the water courses outlets to evaluate the load of microbiological pollutants coming from the rivers and canals. The proposed methodological approach physically based was applied for the delimitation of "no bathing areas" in order to minimize the health risk.

Under the assumed boundary conditions of 1000 and $500 \mathrm{UFC} / 100 \mathrm{ml}$ for E.C. and I.E. respectively, the final results give a precautional value of the width of "no bathing areas" to be $40 \mathrm{~m}$ for artificial outlets and $100 \mathrm{~m}$ for natural deltas along the Ionian coast, while the value for the artificial outlet has been fixed at $20 \mathrm{~m}$ on the Tyrrhenian coast (Fig. 8).

Finally, the study provides the scientific support for robust a suitable identification and delimitation of the "no bathing area" along the coasts even related to those marine-coastal zones potentially involved in short-term pollution events or anomalous circumstances, according to the Directive 2006/7/EC.

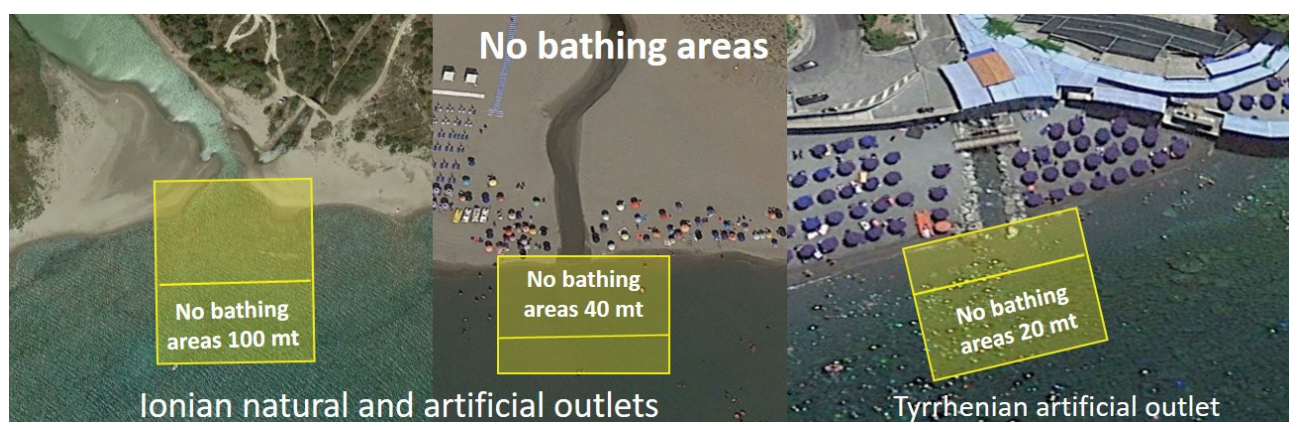

Figure 8: No bathing area for natural and artificial outlets on Ionian and Tyrrhenian seas.

\section{ACKNOWLEDGEMENTS}

This work has been granted by Regione Basilicata - DGR 1490/2014 - Project "Risk Communication and Social Mediation" and carried out by the Engineering School of University of Basilicata - SI-UNIBAS, Regional Environmental Research Foundation - FARBAS in collaboration with Environmental Protection Agency of Basilicata - ARPAB.

\section{REFERENCES}

[1] EC-WFD, Directive 2000/60/EC of the European Parliament and of the Council of 23 Oct. 2000 establishing a framework for Community action in the field of water policy. European Water Framework Directive. Official Journal of the European Communities L 327/1, 2000.

[2] Directive 2006/7/EC of the European parliament and of the council of 15 Feb. 2006 concerning the management of bathing water quality and repealing directive 76/160/EEC. Official Journal of the European Union L 64/37.

[3] Council Directive of 8 Dec. 1975 concerning the Quality of Bathing Water (76/160/EEC) 
[4] Council Directive 91/271/EEC of 21 May 1991 concerning urban waste-water treatment

[5] Council Directive 91/676/EEC of 12 Dec. 1991 concerning the protection of waters against pollution caused by nitrates from agricultural sources.

[6] Malcangio, D. \& Mossa, M., A laboratory investigation into the influence of a rigid vegetation on the evolution of a round turbulent jet discharged within a cross flow. Journal of Environmental Management, 173, pp. 105-120, 2016.

DOI: 10.1016/j.jenvman.2016.02.044.

[7] Ben Meftah, M., Malcangio, D., De Serio, F. \& Mossa, M., Vertical dense jet in flowing current. Environmental Fluid Mechanics, 18, pp. 75-96, 2018.

DOI: 10.1007/s10652-017-9515-2.

[8] Ben Meftah, M., De Serio, F., Malcangio, D. \& Mossa, M., Resistance and boundary shear in a partly obstructed channel flow. River Flow 2016, eds G. Constantinescu, M. Garcia \& D. Hanes, Taylor \& Francis Group: London, pp. 795-801, 2016. ISBN 9781-138-02913-2.

[9] Ben Meftah, M., Malcangio, D. \& Mossa, M., Vegetation effects on vertical jet structures. River Flow 2014, eds A.J. Schleiss, G. De Cesare, M.J. Franca \& M. Pfister, Taylor \& Francis Group: London, 2014, pp. 581-588, 2014.

[10] Favero, M.S., Microbiological indicators of health risks associated with swimming. American Journal of Public Health, 75, pp. 1051-1054, 1985.

DOI: 10.2105/AJPH.75.9.1051.

[11] Noble, R.T., Moore, D.F., Leecaster, M., McGee, C.D. \& Weisberg, S.B., Comparison of total coliform, faecal coliform, and enterococcus bacterial indicator response for ocean recreational water quality testing. Water Research, 37, pp. 1637-1643, 2003.

DOI: 10.1016/S0043-1354(02)00496-7.

[12] Cheung, W.H.S., Chang, K.C.K. \& Hung, R.P.S., Variations in microbial indicator densities in beach waters and health-related assessment of bathing water quality. Epidemiology and Infection, 106, pp. 329-344, 1991.

DOI: $10.1017 / \mathrm{S} 0950268800048482$.

[13] Palazón, A., López, I., Aragonés, L., Villacampa, Y. \& Navarro-González, F.J., Modelling of Escherichia coli concentrations in bathing water at microtidal coasts. Science of The Total Environment, 593-594, pp. 173-181, 2017. ISSN 0048-9697. DOI: 10.1016/j.scitotenv.2017.03.161.

[14] Federigi I., Verani, M. \& Carducci A., Sources of bathing water pollution in northern Tuscany (Italy): Effects of meteorological variables. Marine Pollution Bulletin, 114(2), pp. 843-848, 2017. DOI: 10.1016/j.marpolbul.2016.11.017.

[15] Odonkor, S.T. \& Ampofo J.K., Escherichia coli as an indicator of bacteriological quality of water: An overview. Microbiology Research, 4, pp. e2, 2013.

[16] Bonamano, S. et al., Modeling the dispersion of viable and total Escherichia coli cells in the artificial semi-enclosed bathing area of Santa Marinella (Latium, Italy). Marine Pollution Bulletin, 95(1), pp. 141-54, 2015. DOI: 10.1016/j.marpolbul.2015.04.030.

[17] Portale acque di balneazione - Ministero della Salute. www.portaleacque.salute.gov.it/ PortaleAcquePubblico/.

[18] American Public Health Association. Standard Methods for the Examination of Water and Wastewater, Washington D.C., 1996.

[19] UNI EN ISO 7899-2 Water quality - Detection and enumeration of intestinal enterococci - Part 2: Membrane filtration method (ISO 7899-2:2000). 
[20] EN ISO 9308-1 Water quality - Enumeration of Escherichia coli and coliform bacteria - Part 1: Membrane filtration method for waters with low bacterial background flora (ISO 9308-1:2014).

[21] OMS: Guidelines for safe recreational water environments, OMS Ginevra, 2003.

[22] Delft University of Technology. SWAN Cycle III Version 40.72ABCDE User Manual, Delft, The Netherlands, 2009.

[23] Delft3D-FLOW, Simulation of multi-dimensional hydrodynamic flows and transport phenomena, including sediments, User Manual version 3.15, 24 giugno, 2011,

[24] Deltares, 2011, Delft3D-Flow User Manual, Delft, The Netherlands.

[25] Deltares, 2011, D-Water Quality User Manual (Documentation of the input file), Delft, The Netherlands.

[26] Greco, M. \& Martino, G., Modelling of coastal infrastructure and delta river interaction on ionic Lucanian littoral. Procedia Engineering, 70, pp. 763-772, 2014.

[27] Greco, M. \& Martino, G., Vulnerability assessment or preliminary flood risk mapping and management in coastal areas. Natural Hazards, 82(1), pp. 7-26, 2016.

[28] Greco, M. et al., Integrated SDSS for Environmental Risk Analysis in Sustainable Coastal Area Planning. Computational Science and Its Applications - ICCSA 2018. ICCSA 2018. Lecture Notes in Computer Science, vol 10964, eds O. Gervasi et al., Springer: Cham, 2018. DOI: 1007/978-3-319-95174-4_51.

[29] Menéndez A. \& Laciana C., Pollutant dispersion in water currents under wind action. Journal of Hydraulic Research, 44(4), pp. 470-479, 2006. 